\title{
BANKRUPTCY PRACTICE IN COUNTRIES OF VISEGRAD FOUR
}

\author{
Maria Misankova ${ }^{1}$, Katarina Zvarikova ${ }^{2}$, Jana Kliestikova ${ }^{3}$ \\ ${ }^{1}$ University of Zilina, Department of Economics, Faculty of Operation and Economics of Transport and \\ Communications, Slovak Republic,maria.misankova@fpedas.uniza.sk \\ ${ }^{2}$ University of Zilina, Department of Economics, Faculty of Operation and Economics of Transport and \\ Communications, Slovak Republic, katarina.zvarikova@fpedas.uniza.sk \\ ${ }^{3}$ University of Zilina, Department of Economics, Faculty of Operation and Economics of Transport and \\ Communications, SlovakRepublic, jana.kliestikova@fpedas.uniza.sk
}

\begin{abstract}
Numerous economists and analysts from all over the world have been trying to find an appropriate method to assess company health and to predict its eventual financial distress for many years. No economy is a small isolated subject, and the bankruptcy of a company can cause through its stakeholders' significant impact on the sustainable economic development. Otherwise, companies are very complicated entities, and it is not a simple task to estimate company's future development. Together with the best-known Z-Score model of bankruptcy prediction developed by Altman, numerous models worldwide that are based on different methodologies have been developed. We assume that individual state's economy has major influence on the final form of these models as well as there are several common characteristics between Slovak economy and economy of countries of Visegrad Four. Therefore, we applied chosen bankruptcy prediction models developed in countries of Visegrad Four on the set of Slovak companies and validated their prediction ability in specific condition of the Slovak economy. On the basis of the provided calculations, we compared gained results with the prediction capability of other popular prediction models also applied on the data set of Slovak companies. Through this, we pointed out the importance of the development of unique bankruptcy prediction model, which will be constructed in the specific condition of individual countries, and highlighted the weak forecasting ability of foreign models.
\end{abstract}

Keywords: bankruptcy; financial health; Visegrad Four; prediction models.

JEL Classification: G33

\section{Introduction}

Bankruptcy is one of the most important externalities of current modern economics and even with the maximum effort is not possible to avoid it. Kirkos (2015) and Dichev (1998) also validate that it is one of the most important business decision-making processes. Everywhere where exists investment opportunities are companies willing to assume financial liabilities and resulting risks in order to keep and develop their economic activities.

Corporate failures as well as failures of other subjects represents event that occurs not only in the market economy. Consequences of these failures are far-reaching and have impact on all stakeholders. According to Kumar and Ravi (2007), there are plenty of authors who dedicated their research to the issue of bankruptcy and consider that it is crucially important to pay attention not only to the actual financial situation of the company but also to focus on the prediction of future financial situation.

So in order to achieve good and healthy functioning of the market economy should be the main task given to the prediction of bankruptcy, which represents an important issue not only for banks, insurance companies and corporates but mainly for investors and creditors. On the other hand, also the number of bankruptcies has increased in recent years, and it is becoming harder to estimate, as companies have become more complex and have developed sophisticated schemes to hide their real situation. Therefore, the ability to discriminate between faithful customers from potential bad ones is fundamental for investors, commercial banks, companies and retailers. 
In the economic science, as well as in the practice of real world, a huge variety of models are used for estimating bankruptcy probability of companies and organisations, based on different principles, techniques and methodologies. According to Davydenko and Franks (2008) and Amendola et al. (2013), the prediction ability of these models may vary over time and foreign models may not take into account the particularities of individual economies and may have less accurate predictions. Therefore, respecting the prerequisite that efficient methods can only be applied to companies of the same group in the same economic situation in the period for which the models were originally designed, the main goal of the presented study was the validation of prediction ability of chosen bankruptcy prediction models developed in countries of Visegrad Four in specific condition of the Slovak economy.

\section{Literature Review}

First researches dedicated to the issue of bankruptcy and corporate's failures had arisen in 1930s of the 20th century. These were oriented mainly on the comparison of financial ratios between bankrupt and non-bankrupt companies. Fitzpatrick (1932) published his work oriented on the major differences between successful and unsuccessful businesses. This work had become the inspiration for many of the applied studies that began to emerge in the middle of 1960s of the 20th century.

However, the breakthrough work of Beaver (1966) who applied univariate discriminant analysis that is based on various financial ratios connected into one final predictor serving as a classification criterion is considered as the turning point. Despite a lot of limitations and reservations of this method, it was an inspiration for a large amount of studies devoted to the issue of bankruptcy prediction and corporate failure (Kliestik and Majerova, 2015).

One of the most famous researchers dealing with bankruptcy prediction is Altman (1968) who was the first to apply multivariate discriminant analysis (MDA) for the construction of bankruptcy prediction models. His work is considered as a symbol of prediction of financial health of companies. More than hundreds of authors from different countries, such as Edmister (1972) and Springate (1978), applied this method. MDA is a popular method and, even nowadays, can be found many studies applying that approach. Barreda et al. (2017) proposed MDA bankruptcy prediction model for hospitality firms within the U.S. equity markets. Furthermore, the application of MDA can also be found in Slovakia and other Visegrad countries, such as Gajdka and Stos (1996), Chrastinova (1998), Binkert (1999), Zalai (2000), Wierzba (2000), Gurcik (2002), Prusak (2004), Maczynska (2004), Hamrol et. al. (2004) and Neumaierova and Neumaier (1995, 1999, 2001, 2005).

Another widespread mathematical-statistical method used for the bankruptcy prediction is logistic regression. Logit was first applied by Ohlson (1980), followed later by various researchers. Similar to MDA, logistic regression was also used in models designed in Visegrad countries (Virag and Hajdu, 1996; Michaluk, 2000; Gruszcynski, 2004; Wrzosek and Ziemba, 2009; Hurtosova, 2009).

There are plenty of studies that apply various methods for bankruptcy prediction worldwide. These are probit analysis (Zmijewski, 1984; Kasgari et al., 2013), neural network (Jones et al., 2017; Georgescu, 2017), principal component analysis (Achim et al. 2012; Onofrei and Lupu, 2014), rough sets (Kasgari et al., 2013; Virag and Nyitrai, 2014), data envelopment analysis (Premachandra et al., 2011; Mousavi et al., 2015), decision trees (Tsai et al., 2014; Zieba et al., 2016), support vector machines (Alaminos et al., 2016; Zhao et al., 2017) and others.

\section{Methodology}

The data for the presented study were obtained from annual financial reports of Slovak companies (Register of financial statements, Ministry of Finance of the Slovak Republic) covering the year 2015. Nowadays, Slovak legal system considers company as default according to three criteria:

- the total amount of payable and not payable liabilities is higher than the value of company's assets,

- company has at least two liabilities 30 days after due date from different creditors, 
- the value of financial independence indicator is less than 0.04 .

Additionally, to these criteria, we have detected other relevant characteristics, which are considered as significant according to the Slovak environment (Svabova and Kral, 2016; Svabova and Durica, 2016) to discriminate between bankrupt and non-bankrupt companies. Considering these specifications, we have specified three criteria for the subsequent classification of the company. Thus, the company is included in the bankrupt group of sample if it satisfies the following conditions:

- negative value of earnings after taxes,

- the value of current ratio indicator is less than 1.

- the value of financial independence indicator is less than 0.04 .

Furthermore, to fulfil the given goal of the presented study, we applied chosen bankruptcy prediction models developed in countries of Visegrad Four on the set of Slovak companies and validated their prediction ability in specific condition of the Slovak economy. The final sample consisted of 384 bankrupt (marked 1) and 384 non-bankrupt (marked 0) companies following the suggestion of Agrawal and Maheshwari (2016).

For the purpose of this study, the selection procedure of the bankruptcy prediction models was provided. Based on this, we applied the following models:

Czech model: Neumarierova and Neumaier's model IN05 with the following formula:

$$
\mathrm{IN} 05=0.13 X_{1}+0.04 X_{2}+3.97 X_{3}+0.21 X_{4}+0.09 X_{5}
$$

where

$X_{1}=$ Total assets / Total liabilities

$X_{2}=$ Earnings before interest and taxes / Costs of interest

$X_{3}=$ Earnings before interest and taxes / Total assets

$X_{4}=$ Total revenues $/$ Total assets

$X_{5}=$ Current assets $/$ Short-term liabilities

IN05 $=$ Overall index

Zones of discrimination:

IN05 $>1.60$

Company creates value

$0.90<\mathrm{IN} 05<1.60$

Grey zone of unallocated results - company doesn't create value and also doesn't bankrupt

IN05 $<0.90 \quad$ Company is going to bankruptcy

Poland model: Poznanski's model with the following formula:

$$
\mathrm{PM}=3.562 X_{1}+1.588 X_{2}+4.288 X_{3}+6.719 X_{4}-2.368
$$

where

$X_{1}=$ Net profit $/$ Total assets

$X_{2}=$ Current assets - Stocks $/$ Short-term liabilities

$X_{3}=$ Fixed assets $/$ Total assets

$X_{4}=$ Profit from sales $/$ Revenues from sales 
Zones of discrimination:
$\mathrm{PM}<0$
Bad future financial health of the company
$\mathrm{PM}>0$
Good future financial health of the company

Hungarian model: Virag and Hajda's model with the following formula:

$$
\mathrm{VHM}=1.3566 X_{1}+1.63397 X_{2}+3.6638 X_{3}+0.03366
$$

where

$X_{1}=$ Cash ratio

$X_{2}=$ Cash flow $/$ Total debts

$X_{3}=$ Current assets $/$ Total assets

$X_{4}=$ Cash flow $/$ Total assets

Zones of discrimination:

MVH $<2.61612 \quad$ Possibility of bankruptcy of the company

$\mathrm{MVH}>2.61612 \quad$ Company is classified as solvent / good

To compare gained results with the prediction capability of other popular prediction models, we also applied the following models on the data set of Slovak companies:

American model: Altman's model - for needs of this study, we apply the revised version from the year 2014, which is given as follows:

$$
Z=0.035-0.495 X_{1}-0.862 X_{2}-1.721 X_{3}-0.017 X_{4}
$$

where

$X_{1}=$ Working capital / Total assets

$X_{2}=$ Retained earnings / Total assets

$X_{3}=$ Earnings before interest and taxes / Total assets

$X_{4}=$ Book value of equity / Book value of total liabilities

$Z=$ Overall index

Zones of discrimination:
$Z>2.6$
'Safe' zone
$1.1<Z<2.6$
'Grey' zone
$\mathrm{Z}<1.1$
'Distress' zone

Canadian model: Springate's model with the following discriminant formula:

$$
\mathrm{SM}=1.03 X_{1}+3.07 X_{2}+0.66 X_{3}+0.4 X_{4}
$$


where

$X_{1}=$ Net working capital / Total assets

$X_{2}=$ Earnings before interest and taxes / Total assets

$X_{3}=$ Earnings before taxes / Short-term liabilities

$X_{4}=$ Sales $/$ Total assets

$\mathrm{SM}=$ Overall index

Zones of discrimination:

$0.862<\mathrm{SM}$ Good financial health of the company

$\mathrm{SM}<0.862$ Possible financial problems of the company

The UK model: Taffler's model with formula:

$$
\mathrm{TM}=0.53 X_{1}+0.13 X_{2}+0.18 X_{3}+0.16 X_{4}
$$

where

$X_{1}=$ Earnings before taxes / Short-term liabilities

$X_{2}=$ Current assets $/$ Total liabilities

$X_{3}=$ Short-term liabilities / Total assets

$X_{4}=$ Sales $/$ Total assets

$\mathrm{TM}=$ Overall index

Zones of discrimination:
$\mathrm{TM}>0.3$
Enterprise creates value
$0.2 \leq \mathrm{TM} \leq 0.3$
Grey zone
$\mathrm{TM}<0.2$
Enterprise is going to bankruptcy

Therefore, we applied selected bankruptcy prediction models on the data set of Slovak companies to compare gained classification with the real data and validate prediction ability of these models. The validation was provided based on the confusion matrix and receiver operating characteristic (ROC) curve (Adamko and Svabova, 2016).

Confusion matrix (Table 1) is also referred as contingency table and compares the number of correct and incorrect firms' classification based on the actual and predicted values.

Table 1. Confusion matrix (Source: author's compilation)

\begin{tabular}{|l|l|l|l|l|l|}
\hline \multicolumn{2}{|c|}{} & \multicolumn{2}{|l|}{ Predictive value } & \multicolumn{2}{|l|}{} \\
\cline { 3 - 6 } \multicolumn{2}{|c|}{} & 0 (non-bankrupt) & 1 (bankrupt) & \multicolumn{2}{|l}{} \\
\hline \multirow{2}{*}{$\begin{array}{l}\text { Actual } \\
\text { value }\end{array}$} & 0 (non-bankrupt) & TP & FP & TP + FP & PPV $=$ TP/(TP + FP) \\
\cline { 2 - 6 } & 1 (bankrupt) & FN & TN & FN + TN & NPV $=$ TN/(FN + TN $)$ \\
\hline
\end{tabular}

Table 1 shows the number of predictive and actual values for bankrupt and non-bankrupt companies, where:

- TP (true positives) represents the number of companies predicted by the model as non- 
bankrupt as well as actually non-bankrupt,

- FP (false positives) indicates the number of actually bankrupt companies also predicted by the model as bankrupt, FP is also known as Type I error,

- FN (false negatives) denotes the number of actually bankrupt companies predicted by the model as non-bankrupt, FN is also known as Type II error,

- TN (true negatives) represents the number of companies predicted by the model as bankrupt as well as actually bankrupt,

- PPV (positive predictive value) represents the percentage of correct classification of nonbankrupt companies,

- NPV (negative predictive value) represents the percentage of correct classification of bankrupt companies,

- PV (overall predictive value) indicates the overall prediction ability of the model according to the data set of companies, also known as accuracy of prediction model.

The ROC curve is a graphical technique allowing visual analyses of the trade-offs between the sensitivity and the specificity of a test with regards to the various cut-offs that may be used (Fawcett, 2006). The curve is obtained by calculating the sensitivity and specificity of the test at every possible cut-off point and plotting sensitivity (the proportion of true positive results) against 1 - specificity (the proportion of false positive results). The curve may be used to select optimal cut-off values for a test result, to assess the diagnostic accuracy of a test and to compare the usefulness of different tests.

- ROC parameters calculation is given by following formulas:

$-\quad$ Sensitivity $=\mathrm{TP} /(\mathrm{TP}+\mathrm{FN})$

- False negativity rate $=1-$ Sensitivity $=\mathrm{FN} /(\mathrm{TP}+\mathrm{FN})$

$-\quad$ Specificity $=\mathrm{TN} /(\mathrm{FP}+\mathrm{TN})$

- False positive rate $=1-$ Specificity $=\mathrm{FP} /(\mathrm{FP}+\mathrm{TN})$

- Accuracy (area under the curve)

\section{Results}

During the research process presented in this study, we applied three selected bankruptcy prediction models developed in the countries of Visegrad Four and compared their prediction accuracy in specific condition of Slovakia with three well-known bankruptcy prediction models developed worldwide.

Table 2 shows the results of provided calculations according to the given specifications determined in the methodology part of this study.

Table 2. Confusion matrixes for models applied on the data set of Slovak companies (Source: author's compilation)

\begin{tabular}{|c|c|c|c|c|c|}
\hline \multirow{2}{*}{\multicolumn{2}{|c|}{ IN05 model }} & \multicolumn{2}{|l|}{ Predictive value } & \multirow[b]{3}{*}{384} & \multirow[b]{3}{*}{$38.80 \%$} \\
\hline & & \multirow{2}{*}{$\begin{array}{l}0 \text { (non-bankrupt) } \\
149\end{array}$} & \multirow{2}{*}{$\begin{array}{l}1 \text { (bankrupt) } \\
235\end{array}$} & & \\
\hline \multirow{2}{*}{$\begin{array}{l}\text { Actual } \\
\text { value }\end{array}$} & 0 (non-bankrupt) & & & & \\
\hline & 1 (bankrupt) & 137 & 247 & 384 & $64.32 \%$ \\
\hline & & 286 & 482 & 768 & \multirow[t]{3}{*}{$51.56 \%$} \\
\hline \multirow{2}{*}{\multicolumn{2}{|c|}{ Poznanski's model }} & \multicolumn{2}{|l|}{ Predictive value } & & \\
\hline & & 0 (non-bankrupt) & 1 (bankrupt) & & \\
\hline \multirow{3}{*}{$\begin{array}{l}\text { Actual } \\
\text { value }\end{array}$} & 0 (non-bankrupt) & 361 & 23 & 384 & $94.01 \%$ \\
\hline & 1 (bankrupt) & 27 & 357 & 384 & $92.97 \%$ \\
\hline & & 388 & 380 & 768 & $93.49 \%$ \\
\hline
\end{tabular}




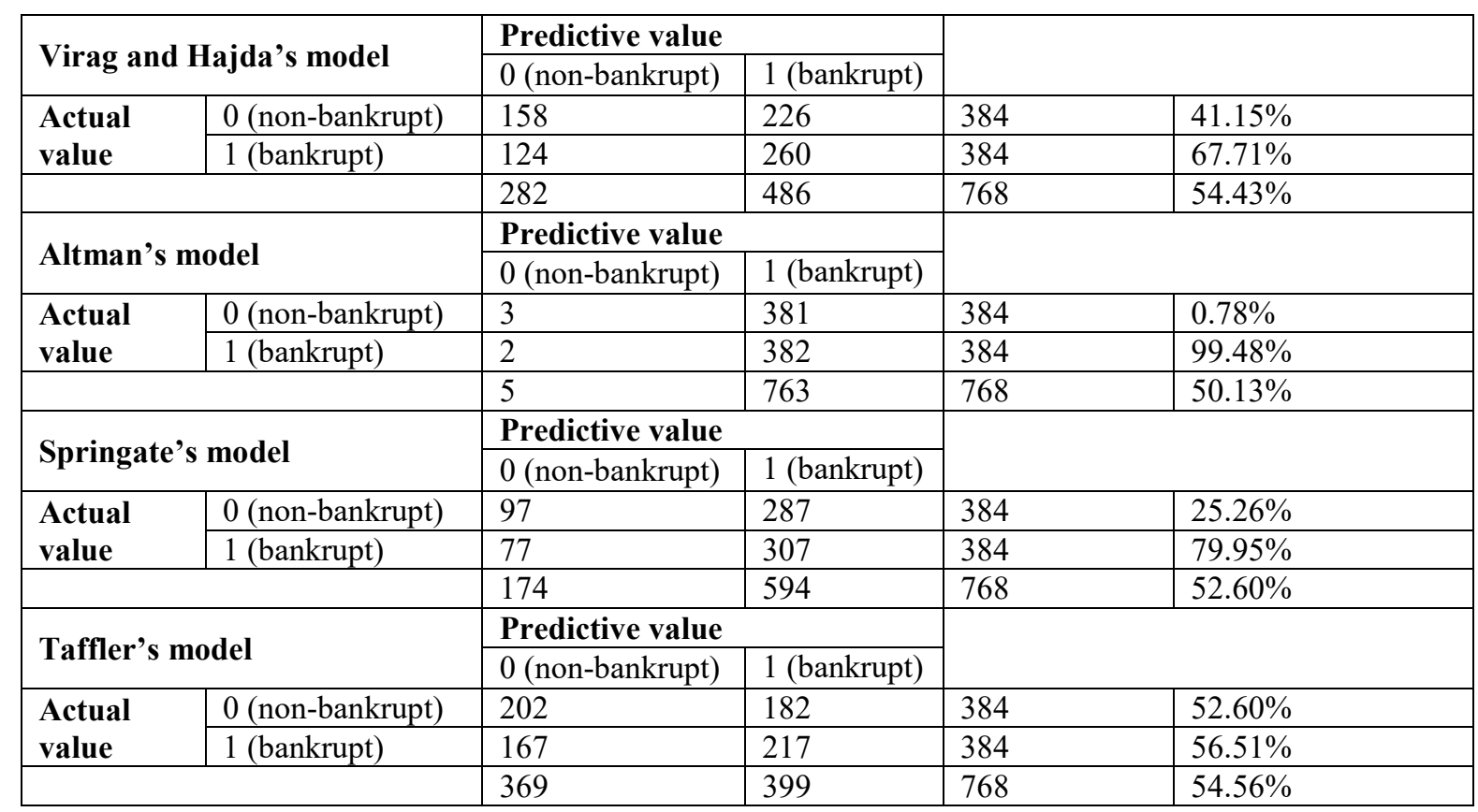

According to the obtained results, it can be concluded that Poznanski's model provided the highest prediction accuracy $(93.49 \%)$ on the data set of Slovak companies. Remaining five prediction models gained similar prediction accuracy a little bit more than $50 \%$. We haven't found significant differences between the Czech model and the Hungarian Model in comparison to other bankruptcy prediction models developed in the world. This is proved also by ROC curve shown in Table 3.

Table 3. Classification results for models applied on the data set of Slovak companies (Source: author's compilation)

\begin{tabular}{|l|c|c|c|c|c|}
\hline & AUC & Sensitivity & False negative rate & Specificity & False positive rate \\
\hline IN05 model & 0.517 & 0.5210 & 0.4790 & 0.5124 & 0.4876 \\
\hline Poznanski's model & 0.935 & 0.9304 & 0.0696 & 0.9395 & 0.0605 \\
\hline Virag and Hajda's model & 0.548 & 0.5603 & 0.4397 & 0.535 & 0.465 \\
\hline Altman's model & 0.550 & 0.6 & 0.4 & 0.5007 & 0.4993 \\
\hline Springate's model & 0.537 & 0.5575 & 0.4425 & 0.5168 & 0.4832 \\
\hline Taffler's model & 0.546 & 0.5474 & 0.4526 & 0.5439 & 0.4561 \\
\hline
\end{tabular}

On the basis of these results, we can see that more than $93 \%$ of Slovak companies from data set in this study were correctly classified by Poznanski's model. This is proved also by the calculated sensitivity and specificity of this model. Although this model gained very high prediction accuracy, other models gained relatively low sensitivity and specificity and prediction accuracy.

Furthermore, gained results can be graphically illustrated by ROC curves for each model (Fig. 1), representing the ability of each model to discriminate between bankrupt and non-bankrupt companies. 
a)

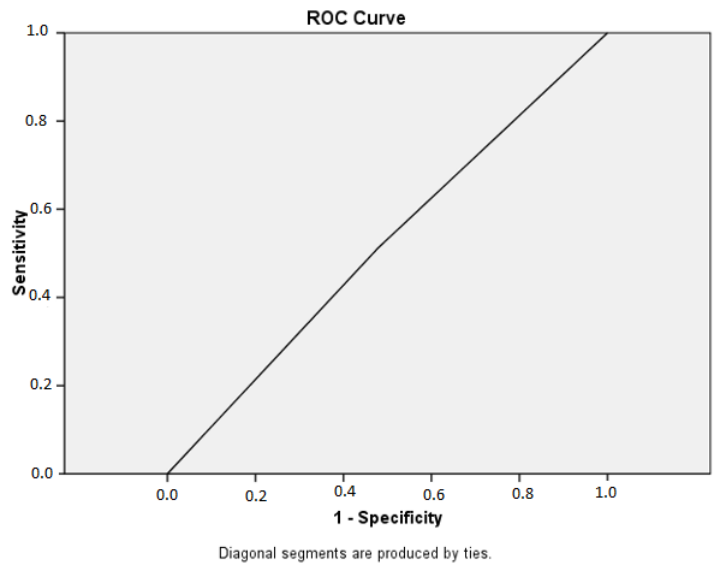

(c)

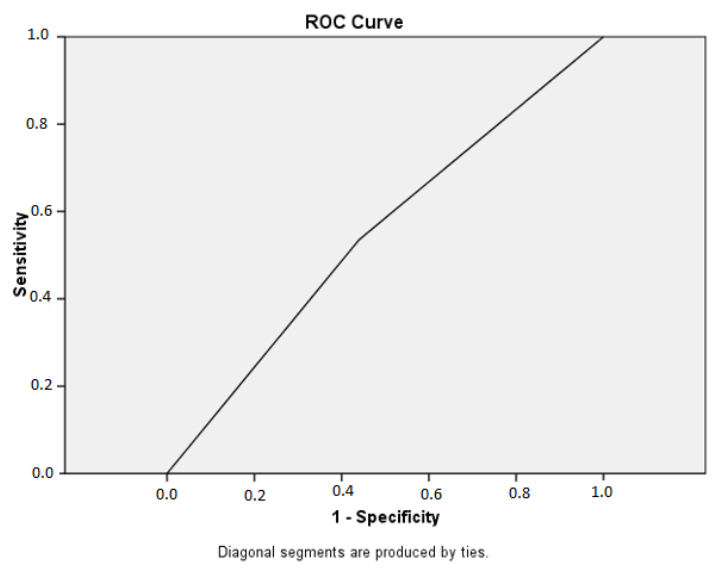

(e)

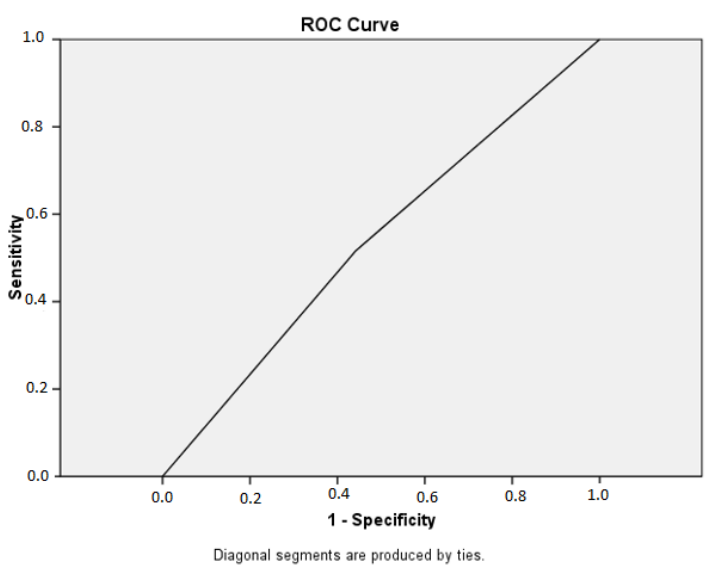

(b)

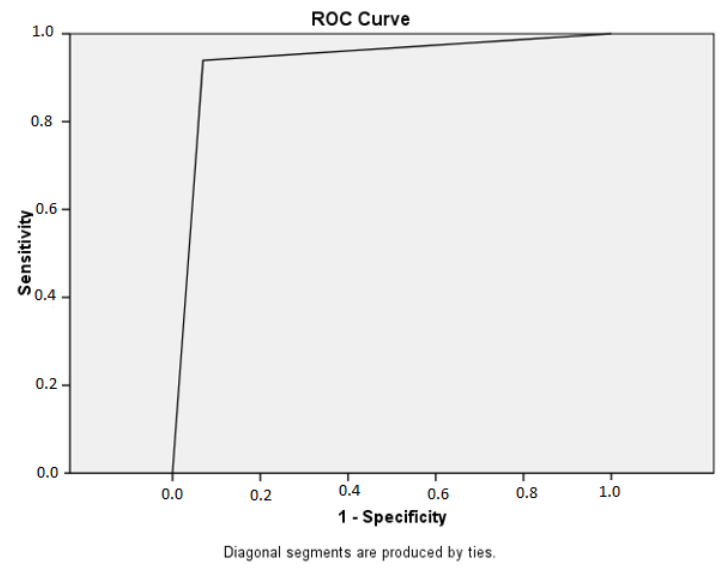

(d)

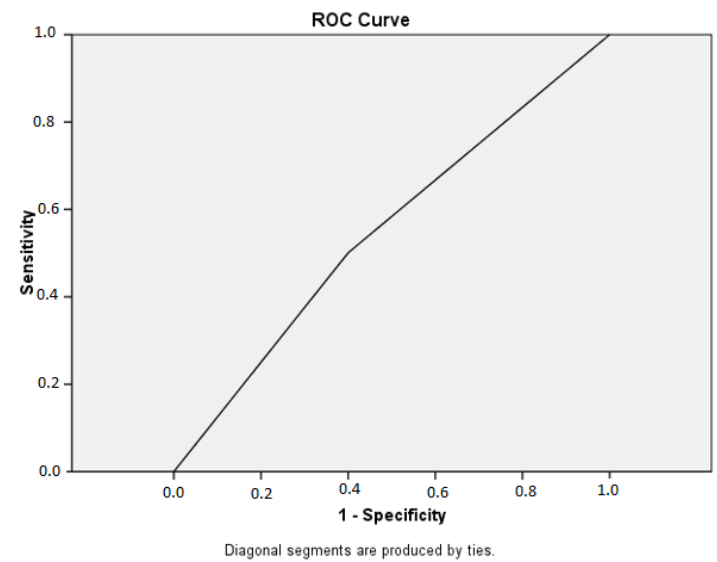

(f)

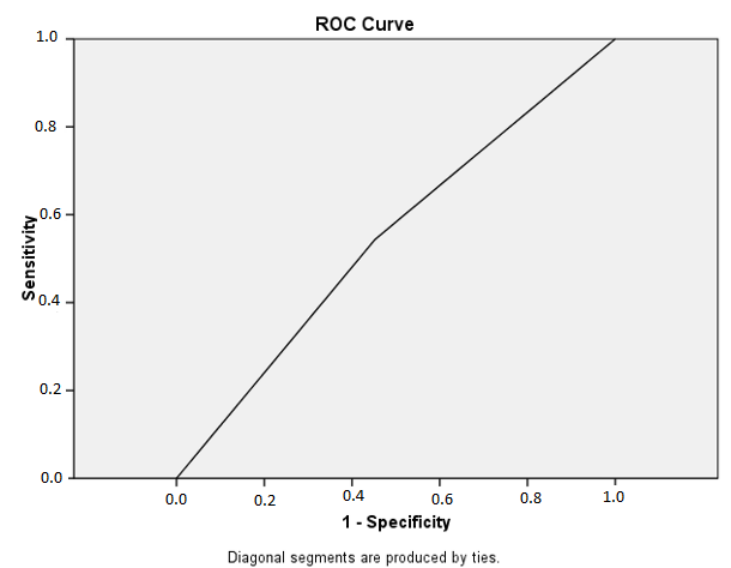

Fig. 1. ROC curves for models applied on the data set of Slovak companies: (a) IN05 model, (b) Poznanski's model, (c) Virag and Hajda's model, (d) Altman's model, (e) Springate's model and (f) Taffler's model (Source: author's compilation)

\section{Conclusions}

Despite the plenty of researches and publications dedicated to the issue of bankruptcy prediction, there are not many Slovak models that forecast the probability of bankruptcy with high prediction accuracy. On the other side, there have been numerous bankruptcy prediction models developed worldwide, but 
the applicability of a model can vary depending on the specifics of national economies, industry and other factors.

So the presented study has attempted to test these prerequisites, if the model developed in foreign country can be successfully used in other country. Therefore, we applied chosen bankruptcy prediction models developed in the countries of Visegrad Four on the data set of Slovak companies. We assume that these countries have similar economies and other several common characteristics with Slovakia, so we expected that the prediction accuracy would be higher than that of other popular prediction models also applied on the data set of Slovak companies.

On the basis of the gained results, it can be concluded that models constructed in Visegrad Four reached better prediction ability than other three models; in the case of Poznanski's model, it is more than $90 \%$, but other models proved (prediction accuracy only little bit more than $50 \%$ ) that it is highly important to develop a unique bankruptcy prediction model, which will be constructed in the specific condition of individual countries, especially in the Slovak republic. This was proved and highlighted by the weak forecasting ability of foreign models applied on the data set of Slovak companies, and it doesn't matter so much if the model was developed in country with similar economy or somewhere else.

\section{Acknowledgements}

This work was supported by the Slovak Research and Development Agency under Grant number APVV-14-0841: Comprehensive Prediction Model of the Financial Health of Slovak Companies.

\section{References}

Achim, M.V., Mare, C., \& Borlea, S.N. (2012). A statistical model of financial risk bankruptcy applied for Romanian manufacturing industry. International Conference on Emerging Markets Queries in Finance and Business, Conference Proceedings, 132-137.

Adamko, P., \& Svabova, L. (2016). Prediction of the risk of bankruptcy of Slovak companies. Proceedings of $8^{\text {th }}$ International Scientific Conference Managing and Modelling of Financial Risks, Conference proceedings, 1520.

Agrawal, K., \& Maheshwari, Y. (2016). Predicting financial distress: revisiting the option-based model. South Asian Journal of Global Business Research, 5(2), 268-284

Alaminos, D., delCastillo, A., \& Fernandez, M.A. (2016). A Global Model for Bankruptcy Prediction. Plus One, 11(11), e0166693.

Altman, E. I. (1968). Financial Ratios, Discriminant Analysis and The Prediction of Corporate Bankruptcy. The Journal of Finance, 23(4), 589-609.

Altman, E. I., Iwanicz-Drozdowska, M., Laitinen, E.K., \& Suvas, A. (2014). Distressed Firm and Bankruptcy Prediction in an International Context: A Review and Empirical Analysis of Altman's Z-Score Model. 1-47. [Accessed 10.04.2017]. Available from Internet: https://poseidon01.ssrn.com/delivery.php?ID=52910609308707501312706708400101312602906902905305902 402310408601011907110909611102303301006203705709810510908708612110800600500504905308100308 410412211611711406900104900200702512411508611707301708409708806908306501010907200000107408 $6091124086118014066 \& \mathrm{EXT}=\mathrm{pdf}$

Amendola, A, Restaino, M., \& Sensini, L. (2013). Corporate Financial Distress And Bankruptcy: A Comparative Analysis. In The 6th Annual Euromed Conference Of The Euromed-Academy-Of-Business. Conference proceedings, 107-120.

Barreda, A.A., Kageyama, Y., Singh, D., \& Zubieta, S. (2017). Hospitality Bankruptcy in United States of America: A Multiple Discriminant Analysis-Logit Model Comparison. Journal of Quality Assurance in Hospitality \& Tourism, 18(1), 86-106.

Beaver, W. (1966). Financial Ratios as Predictors of Failure, Empirical Research in Accounting: Selected Studies. Supplement to the Journal of Accounting Research, (4), 71-111.

Binkert, Ch. H. (1999) Fruherkennung von Unternehmenskrisen mit Hilfe geeigneter Methoden im deutschen 
und slowakischen Wirtschaftsraum. Dissertation.

Chrastinova, Z. (1998). Metódy hodnotenia ekonomickej bonity a predikcie finančnej situácie polnohospodárskych podnikov. Bratislava: VÚEPP.

Davydenko, S., \& Franks, Jr. (2008) Do Bankruptcy Codes Matter? A Study of Defaults in France, Germany, and the UK. Journal of Finance, 63(2), 797-1022.

Dichev, I.D. (1998). Is The Risk Of Bankruptcy A Systematic Risk? Journal of Finance, 53(3), 1131-1147.

Edmister, R.O. (1972). Financial Ratios as Discriminant Predictors of Small Business Failure. Journal of Finance, 27(1), 1-178.

Fitzpatrick, P.J. (1932). A Comparison of Ratios of Successful Industrial Enterprises with Those of Failed Firms, Certified Public Accountant, (10), 598-605.

Gajdka J., \& Stos, D. (1996). Wykorzystanie analizy dyskryminacyjnej w ocenie kondycji finansowej przedsiębiorstw, Materiaty z Ogólnopolskiej Konferencji Naukowej „Restrukturyzacja w procesie przekształceń $i$ rozwoju przedsiębiorstw", Wydawnictwo Akademii Ekonomicznej w Krakowie, Wydawnictwo Akademii Ekonomicznej, Kraków, Conference proceedings, 56-65.

Georgescu, V. (2017). Using genetic algorithms to evolve type-2 fuzzy logic systems for predicting bankruptcy. Kybernetes, 46(1), 142-156.

Gruszczynski, M. (2004) Financial distress of companies in Poland. International Advances in Economic Research, 10(4), 249-256.

Gurcik, L. (2002). G-index - the financial situation prognosis method of agricultural enterprises. Agricultural Economics, 48(8), 373-378.

Hamrol, M., Czajka, B., \& Piechocki, M. (2004). Company bankruptcy - a discriminant analysis model Upadłość przedsiębiorstwa - model analizy dyskryminacyjnej. Przegląd Organizacji, (6), 35-39.

Hurtosova, J. (2009). Konštrukcia ratingového modelu, nástroja hodnotenia úverovej spôsobilosti podniku, dissertation thesis, Economic University in Bratislava, Bratislava.

Jones, S., Johnstone, D., \& Wilson, R. (2017). Predicting Corporate Bankruptcy: An Evaluation of Alternative Statistical Frameworks. Journal of Business \& Accounting, 44(1-12), 3-34.

Kasgari, A.A., Divsalar, M., Javid, M.R., \& Ebrahimian, S.J. (2013). Prediction of bankruptcy Iranian corporations through artificial neural network and Probit-based analyses. Neural Computing \& Applications, 23(3-4), 927-936.

Kirkos, E. (2015). Assessing Methodologies for Intelligent Bankruptcy Prediction. Artificial Intelligence Review, 43(1), 83-123.

Kliestik, T., \& Majerova, J. (2015). Selected issues of selection of significant variables in the prediction models. Proceedings of 10th international scientific conference Financial management of firms and financial institutions, Conference proceedings, 537-543.

Kumar, P., \& Ravi, V. (2007). Bankruptcy Prediction In Banks And Firms Via Statistical And Intelligent Techniques - A Review, European Journal Of Operational Research, 180(1), 1-28.

Mączynska, E., (2004). Globalizacja ryzyka a systemy wczesnego ostrzegania przed upadłością przedsiębiorstwa. Upadtość przedsiębiorstw w Polsce w latach 1990-2003. Teoria i praktyka. Poznań.

Michaluk, K. (200). Zastosowania metod ilosciowych w procesie przewidywania zagrozenia upadloscia przedsiebiorstwa. doctoral dissertation, Uniwersytet Szczeciński, Szszecin.

Mousavi, M.M., Ouenniche, J., \& Xu, B. (2015). Performance evaluation of bankruptcy prediction models: An orientation-free super-efficiency DEA-based framework. International Review of Financial Analysis, (42), 6475 .

Neumaier, I., \& Neumaierová, I. (1995). Zkuste spočítat svůj INDEX IN 95. Terno, (5).

Neumaier, I., \& Neumaierová, I. (1999). Finanční analýza INFA - Aplikace na energetiku. Sektorové a odvětvové analýzy Aspekt Energetika, 4(1), 32-75.

Neumaier, I., \& Neumaierová, I. (2001). Analýza tvorby hodnoty - aplikace finanční analýzy INFA. Sektorové a odvětvové analýzy Aspekt 8/V Investični strojirenství, 23-39. 
Neumaier, I., \& Neumaierová, I. (2005). Index IN 05. Proceeding of the conference „European financial systems", Conference proceedings, 143-148.

Ohlson, J.A. (1980) Financial ratios and the probabilistic prediction of bankruptcy. Journal of Accounting Research, 18(1), 109-131.

Onofrei, M., \& Lupu, D. (2014). The Modeling of Forecasting the Bankruptcy Risk in Romania. Economic Computation and Economic Cybernetics Studies and Research, 48(3), 197-215.

Premachandra, I.M., Chen, Y., \& Watson, J. (2011). DEA as a tool for predicting corporate failure and success: A case of bankruptcy assessment. Omega - International Journal of Management Science, 39(6), 620-626.

Prusak, B. (2004). How to recognise a potential bankrupt? Assessment of company insolvency risk, based on multiple discriminant analysis. [Accessed 10.04.2017]. Available from Internet: http://www1.zie.pg.gda.pl/ pb/jrpb.pdf

Springate, G.L.V. (1978). Predicting the possibility of failure in a Canadian firm. Unpublished MBA Res. project, Simon Fraser Univ., 42-47.

Svabova, L., \& Durica, M. (2016). Korelačná analýza prediktorov použitých v bankrotných predikčných modeloch na Slovensku. Ekonomicko manazerske spektrum, 10(1), 2-11.

Svabova, L., \& Kral, P. (2016). Selection of predictors in bankruptcy prediction models for Slovak companies. Proceedings of $10^{\text {th }}$ International days of statistics and economics, Conference proceedings, 1759-1768.

Taffler, R.J., \& Tseung, M. (1984). The Audit Going-Concern. Practise. Accountant's Magazine, (88), 263-269.

Tsai, C.F., Hsu, Y.F., \& Yen, D.C. (2014). A comparative study of classifier ensembles for bankruptcy prediction. Applied Soft Computing, (24), 977-984.

Virag, M., \& Hajdu, O. (1996) Pénzügyi mutatószámokon alapuló csõdmodellszámítások. Bankszemle XV, (5), 42-53.

Virag, M., \& Nyitrai, T. (2014). Is There A Trade-Off Between The Predictive Power And The Interpretability Of Bankruptcy Models? The Case Of The First Hungarian Bankruptcy Prediction Model. Acta Oeconomica, 64(4), 419-440.

Wierzba, D. (2000). Wczesne wykrywanie przedsiębiorstw zagrożonych upadłościa na podstawie analizy wskaźników fi nansowych - teoria $i$ badania empiryczn e. „Zeszyty Naukowe” 9, Wyd. Wyższej Szkoły Ekonomiczno-Informacyjnej w Warszawie, Warszawa.

Wrzosek, M., \& Ziemba, A. (2009). Construction of a rating based on a bankruptcy prediction model. Credit Research Center, The University of Edinburgh, 1-19, [Accessed 08.04.2017]. Available from Internet: http://www.business-school.ed.ac.uk/crc/conferences/conference-archive?a $=45910$

Zalai, K. (2000). Special Aspects of Forecasting the financial development of Slovak companies. BIATEC, 8(1), 12- 14.

Zhao, D., Huang, C.Y., Wei, Y., Yu, F.H., Wang, M.J., \& Chen, H.L. (2017). An Effective Computational Model for Bankruptcy Prediction Using Kernel Extreme Learning Machine Approach. Computational Economics, 49(2), 325-341.

Zieba, M., Tomczak, S.K., \& Tomczak, J.M. (2016). Ensemble boosted trees with synthetic features generation in application to bankruptcy prediction. Expert Systems with Applications, (58), 93-101.

Zmijewski, M. E. (1984) Methodological issues related to the estimation of financial distress prediction models. Journal of Accounting Research, (22), 59-82. 